\title{
Tributación y reorganización del trabajo indígena en Venezuela (1687-1697)
}

\author{
Fabricio Vivas Ramírez \\ Instituto de Estudios Hispanoamericanos, \\ Universidad Central de Venezuela
}

\begin{abstract}
Durante casi siglo y medio, los encomenderos de Venezuela usufructuaron el tributo en "servicio personal" como la principal forma de explotar el trabajo indígena. Al final del siglo XVII, circunstancias de orden político y legal si bien presionaban sobre el viejo sistema por necesarios cambios, nuevas condiciones fiscales pronto le imprimieron algunas reformas y, de hecho, lo llevaron a su desaparición cuando en 1687 se impuso la tributación en "dinero". Con el establecimiento del nuevo régimen de tributación también se dieron las normas que regulaban la forma de pago y las tasas de acuerdo a su jurisdicción, así como el ajuste en la asignación de los estipendios de curas doctrineros que desde entonces dependieron del tributo indígena. Este sistema no sólo se extendió con rapidez hasta los pueblos más distantes de la gobernación, sino que además impulsó la oferta de una fuerza de trabajo que se contrató en condiciones más liberales.
\end{abstract}

\section{Introducción}

El presente trabajo responde a la imperiosa necesidad de profundizar un poco más en torno a la reconstrucción del complejo y heterogéneo desarrollo socio histórico de los pueblos indígenas. En Venezuela, hasta hoy, a pesar de algunos resultados parciales, la investigación sobre la temática resulta muy poco satisfactoria, pues todavía sigue pendiente la redacción de una obra de historia general, que ni siquiera existe a nivel de manual, sobre el devenir de las comunidades y pueblos aborígenes que ocuparon las distintas regiones de Tierra Firme. ${ }^{2}$

En esta oportunidad, para un lapso sumamente corto como el de una década y una región tan concreta como la antigua provincia de Venezuela,

1 El artículo resultó del seminario: "Jueces y Visitadores en los Pueblos de Indios bajo la administración española", como parte del programa doctoral (curso académico 1999-2000): "Historia y Sociedad en las Américas" a cargo del Departamento de Historia de América de la Universidad de Sevilla. El curso fue dirigido por el Dr. Julián B. Ruiz Rivera, a quién agradezco sus críticas.

2 Aun cuando el asunto no se aborda en este momento, se recomienda el minucioso trabajo realizado por Hidalgo Nuchera, Patricio y Mudarás García, Félix: La Encomienda en América y Filipinas. Su impacto sobre la realidad socioeconómica del mundo indígena. Bibliografía. Madrid, Notigraf, 1999. Esta obra si bien recoge y clasifica por tópicos una parte importante de la producción historiográfica sobre el origen y evolución de la organización del trabajo indígena, también da una clara evidencia de los escasos resultados de investigación para la antigua provincia Venezuela. 
intento rescatar los cambios que se generaron en la tributación indígena a partir de 1687, cuando por fin se derogó el "servicio personal" y en consecuencia se impuso la tributación en "dinero" o su equivalente en especie y que, hacia 1697, la recaudación de la renta se desarrollaba paralela y en cierta armonía con la reorganización del trabajo indígena. Pero también, espero que dichos cambios respondan y formen parte de la continuidad que experimenta la organización y la explotación del trabajo en el largo devenir histórico, al tiempo que explique su particular proceso regional.

\section{Encomienda de servicio personal}

La institución de la encomienda en la provincia de Venezuela se estableció unos años antes de mediar el siglo XVI. Por aquel tiempo, los vecinos y el gobierno provincial después de alegar la gran pobreza de la tierra y con ella, la de los indígenas para tributar en "especie", adoptaron el sistema del "servicio personal" como la mejor forma para explotar su fuerza de trabajo, por el cual los encomenderos a cambio de la protección y la evangelización, pasaron a cobrar un servicio que transformaron en trabajo obligado y cuya labor se tasó en tres días a la semana que los naturales realizarían en el campo o las ciudades. ${ }^{3}$

A pesar de las leyes que la Corona dictó hasta bien entrado el siguiente siglo contra el servicio personal, a fin de generalizar la tributación en dinero y la moderación de sus tasas, los vecinos desde los respectivos cabildos y con apoyo del gobernador, consiguieron a través de las reiteradas peticiones económicas elevadas ante los reyes que la servidumbre indígena prevaleciera, pues tal servicio constituía la base de la producción agrícola y no podían prescindir de ella. Pero al mismo tiempo, las particulares condiciones que sustentaban el débil desarrollo del tradicional sistema, tanto por la falta de cumplir con algunas leyes que permitieran su regulación

3 Sobre la encomienda existe una abundante producción intelectual para Hispanoamérica que tratan los orígenes y su desarrollo histórico. Respecto a la provincia de Venezuela, se recomiendan los estudios de obligada consulta ya clásicos y varias veces reeditados de Arcila Farías, Eduardo: Economía Colonial de Venezuela, Caracas, Italgráfica, 1973, 2 vols.; del mismo: El régimen de la encomienda en Venezuela, Caracas, Universidad Central de Venezuela, 1979; y Arellano Moreno, Antonio: Orígenes de la economía venezolana, Universidad Central de Venezuela, 1975. Más recientemente contamos con los trabajos de Da Pratto-Perelli, Antoniette: Las encomiendas de Nueva Andalucía en el siglo XVII. La visita hecha por don Fernando de la Riva Agüero, oidor de la Audiencia de Santo Domingo, 1688. Caracas, Academia Nacional de la Historia, 1990, 4 vols.; y Rojas, Reinaldo: El régimen de encomienda en Barquisimeto colonial, 1530-1810, Caracas, Academia Nacional de la Historia, 1992. 
y control, como por las cargas que pechaban los beneficios del trabajo indígena y donde incidía de forma especial la renta de media anata, entre otros hechos, al final del último tercio del siglo XVII ya exigían inmediatas reformas.

\section{El tradicional sistema de explotación}

\section{La conservación del régimen}

$\mathrm{Al}$ igual que por muchos años, durante el primer quinquenio de 1680 el gobierno provincial de Venezuela, a fin de cumplir con la regular asignación de las encomiendas de indios vacantes y subordinadas a distintos pueblos en doctrina, continuó con la tradicional práctica de los edictos para otorgar su administración. Convocadas a público remate entre los vecinos opositores que concurrieran, en torno a los que más pujaran se entregaban las respectivas provisiones de encomiendas hasta entonces en cabeza de la Corona. Pero al final, la preferencia para la concesión dependía de muchos factores, sobresaliendo entre ellos tanto la amistad con el gobernador como el que alegaran cualesquier servicios prestados a la monarquía, o bien algunas manifestaciones en defensa de la Santa Iglesia Católica, con lo cual, pasaban a usufructuar las encomiendas hasta por dos vidas conforme a la ley de sucesión. ${ }^{4}$

A través de los títulos expedidos por el gobernador y siempre en nombre del rey, los nuevos encomenderos se obligaban a pagar algunas rentas al erario real, por concepto de "composición de indios", las "demoras y aprovechamientos" por los indígenas repartidos y la "pensión general de indios" que se aplicaban sobre las mercedes recibidas. El provecho de la pensión, en principio, continuó financiando una lista cada vez mayor de

4 Así lo evidencian las cédulas al momento de confirmar algunas encomiendas, como ocurrió, por ejemplo, con Bartolomé Pan y Agua de Trexo, que por muerte del capitán Simón Suárez recibió (1681, agosto) la encomienda de indios del valle de Boconó, jurisdicción de la ciudad de Trujillo; el sargento mayor Luis de Silva y Piña, que por muerte de Lucía de León y Piña recibió (1682, diciembre) la de los indígenas de nación Cayones, asignados al pueblo de doctrina San Antonio de los Naranjos en el valle de Umucaro, jurisdicción de la ciudad de El Tocuyo; o la de Alonso Moxica Santillán, vecino de Barquisimeto, que por muerte de Elvira de Ponte y Alvarado recibió (1684, agosto) los aborígenes de nación Ajaguas, Camayos, Gayones y Coyones, asignados a los pueblos y doctrinas de los valles de Quivor y Umucaro, jurisdicción de El Tocuyo. Archivo General de la Nación, Caracas (en adelante AGN-C), Sección Real Hacienda, Libro Copiador de Reales Cédulas y Títulos, que corren desde 1682 hasta el año de 1702. Caracas, 1682-1702, Tomo 462, fols. 106-108. 
actividades locales, como eran las destinadas a pagar la infantería de la fuerza y plataforma del puerto de La Guaira, el preceptor de gramática situado en la ciudad de Santiago de León y la limosna para vino y aceite que se distribuía entre los escasos conventos de la provincia. ${ }^{5}$

El producto de los beneficios particulares derivados por el disfrute de las encomiendas disminuía por numerosas deducciones. Los descuentos ya no sólo incluían los tradicionales derechos al fisco o los gastos propios del encomendero por la protección y evangelización del indígena; también estaban sujetos los encomenderos a cualquier contingencia, de acuerdo a las resoluciones que se tomaran sobre las demoras de los indígenas o bien de imprevistas contribuciones graciosas al rey; a ello se añadían los fletes por la obligación de tener que presentar en los siguientes cinco años ante los jueces oficiales de Hacienda la confirmación del monarca. Pero lo que más inquietaba a los vecinos era que, para la conservación de aquellas encomiendas, progresivamente vieran aumentar en gran cantidad sus costas, al tener que sufragar nuevas obligaciones como el dar bulas a todos sus encomendados a fin de contribuir con la Santa Cruzada, así como medio real al día, para el sustento de cada uno de los naturales que trabajaran en sus haciendas.

\section{La protección del indígena}

En cuanto a mantener el buen tratamiento y conservación de los indígenas, sus vasallos, fueron numerosas las medidas, que hasta entonces la dinastía de los Austrias ordenó por igual a virreyes, oidores y gobernadores al momento de entrar a servir sus puestos en las Indias. Política protectora que observarían precisa y puntualmente, pues en caso contrario, y advertidos de cualquier falta, no sólo se les seguiría juicio con cargo en la residencia pues era materia de expreso castigo y se actuaría con toda severidad como a transgresores de aquellas órdenes, sino que, además, la imposición de tales sanciones constituiría una medida ejemplar para futuros casos. ${ }^{6}$

5 La obligación de la Pensión General de Indios correspondió a una renta anual, variable al momento de la asignación, que se impuso sobre todas las encomiendas y llevaban consigo para su posesión y goce.

6 De ello existen numerosas referencias documentales no sólo a raíz de los juicios de residencia, sino también por las acciones adelantadas y resultados conseguidos a través de las comisiones ya fueran por pesquisas secretas o visitas por denuncias contra determinadas autoridades. 
No obstante, fueron órdenes que de igual modo la Corona prosiguió recordando a los distintos funcionarios. Así lo registran numerosos títulos. Por ejemplo, para ejercer las tareas tanto de gobernador como capitán general de Venezuela que, entre otras muchas obligaciones de naturaleza política, civil, criminal y militar, dependientes de los dos cargos, también respondían por el cuidado y protección de los pueblos indígenas. Con todo, el Consejo de Indias conocía las continuas vejaciones y agravios que recibían los aborígenes, cuando los gobernadores salían a las ordinarias visitas y regulares comisiones hacia la tierra adentro y donde los despojaban de sus víveres para reponer el bagaje de la tropa, por lo que les recordaba en las cédulas:

cuando vayáis a tomar posesión del dicho oficio ni cuando salgáis de visita ordinaria de la provincia ni otras comisiones, no obliguéis a los indios a que den bastimentos ni bagajes, sino que esto sea voluntario en ellos, pagándoles justamente lo que se les debiere, según el común precio o estimación de las cosas que hubiéredes menester, sin hacerles perjuicio de vejación alguna, por lo que se debe atender a su alivio y conservación y ser materia tan escrupulosa y digna de todo reparo.?

\section{Condiciones que empujan a su modificación}

\section{El incumplimiento de las leyes}

Por distintas cédulas dirigidas a las autoridades superiores de la provincia estaba mandada la estricta aplicación de todas las leyes sobre la atención indígena; pero cual sería la realidad en Venezuela, que al momento de cumplir con la obligación de algunos capítulos sobre la organización de los pueblos aborígenes, éstos nunca se habían aplicado. Así sucedía, por ejemplo, en cuanto a vigilar la buena gestión y administración de los corregidores sobre el cobro del tributo indígena. ${ }^{8}$ En este caso se le ordenaba al gobernador Diego Melo de Maldonado, como también a sus antece-

7 AGN-C, Real Hacienda, Libro Copiador, T. 462, fol. 7vto. Cédula de 1682, por la cual se confieren los títulos y nombramiento como gobernador y capitán general de Venezuela, a Diego Melo de Maldonado, caballero de la orden de Calatrava.

8 En su último trabajo, el Dr. Suárez dedicó el epígrafe "Los fiscales y la tasación de los tributos de indios" para estudiar el desarrollo del sistema tributario indígena durante el siglo XVI americano. Suárez, Santiago-Gerardo: Los Fiscales Indianos. Origen y evolución del Ministerio Público. Caracas, Academia Nacional de la Historia, 1995, págs. 435-447. 
sores, que de no hacer cumplir el precepto, con pena y sin admitir diligencias ni descargos en la residencia, sería juzgado y sentenciado en cualquier instancia:

cobraréis los tributos de los indios de vuestro distrito que debieren pagar y no lo haciendo, pagaréis de vuestra hacienda los resagos que en vuestro tiempo se causaren como tenéis obligación, ... so pena que no cobrando los dichos tributos, pagarán vuestros fiadores lo que de ello dejare de cobrar. ${ }^{9}$

De igual modo ocurría respecto al cuidado con las cajas de comunidad de los indígenas, que de hecho no existían. ${ }^{10} \mathrm{Si}$ bien estaba prohibido por diversas cédulas y ordenanzas reales que ninguna autoridad extrajera cosa alguna, se tenían noticias de otros territorios donde muchos gobernadores y corregidores de indios, contraviniendo lo establecido, sacaban de aquellas cajas la plata y otros bienes que existían para emplearlos en sus tratos, granjerías y usos propios, con lo cual generaban muchos perjuicios a los naturales. En tales casos el rey mandaba:

habéis de estar advertido que en ninguna manera habéis de tocar a las dichas cajas de comunidad de los indios, por ningún caso ni para ningún efecto que sea ni servicios de ellos, ni ocuparlos en ningunos ministerios de vuestro servicio, con apercibimiento de que se os hará cargo con vuestra residencia y seréis castigado por ello con demostración. ${ }^{11}$

Pero a todas luces lo más importante que estaba ordenado a los gobernadores en las posesiones de las Indias, y hasta entonces no cumplido en Venezuela, se refería a los padrones de indios. Esta consistía en una medida de gran interés entre la Real Hacienda y la Iglesia, no sólo para conocer las condiciones y número de la población aborigen, sino también para estimar algunos montos y establecer de una vez por todas la recaudación del tributo indígena en dinero ya con larga tradición en otros lugares de Hispanoamérica. ${ }^{12}$ El empadronamiento de indios tributarios lo realizaría el gobernador, "al tiempo que entráredes a servir el dicho oficio como está dispuesto por la Ordenanza que hizo don Francisco de Toledo,

9 AGN-C, Real Hacienda, Libro Copiador, T. 462, fol. 8.

10 Suárez: Los Fiscales, págs. 357-375. En el epígrafe "Cajas de Comunidad y Cajas de Censos", el autor reconstruye el devenir histórico de estas Cajas desde los primeros momentos de la conquista hasta el siglo XVIII indiano.

11 AGN-C, Real Hacienda, Libro Copiador, T. 462, fol. 8.

12 Arcila: El régimen, pág. 274. 
siendo mi virrey de las provincias del Perú, que está confirmada por provisión real". ${ }^{13}$

\section{La renta que más pesa sobre la encomienda}

La violencia de los continuos ataques piráticos contra las posesiones hispanas en América, y sobre todo en la extensa jurisdicción de Nueva España, exigió con la mayor prontitud ingentes recursos para su defensa, pues al no alcanzar los que por concepto de media anata ingresaban a las cajas principales de las regiones que correspondían al virreinato, resultaba sumamente necesario disponer de las que pertenecían a otras provincias americanas..$^{14}$ En tal sentido y por una cédula dirigida al gobernador de Venezuela, dictada el 2 de septiembre de 1687, se avisó la resolución para sustraer de la media anata de todas las encomiendas de indios en los reinos de Nueva España, Perú y Tierra Firme la mitad de lo líquido del valor de ellas, deducidas primero las cargas pertenecientes a la Real Hacienda. ${ }^{15} \mathrm{El}$ gravamen, fijado por tiempo de cuatro años y que empezaría a correr desde el $1^{\circ}$ de enero de 1688 , se destinaría para establecer y mantener fuerzas navales en los mares del Sur y del Norte, con las cuales defender y asegurar las costas y sus comercios de los repetidos ataques de piratas. A consulta del Consejo de Indias, se mandó al gobernador, respecto a la media anata, que diera las oportunas ordenes:

para que de todos los repartimientos de indios que con nombre de encomiendas hubiere en esa provincia de Venezuela, se desfalque la mitad por tiempo de cuatro

13 AGN-C, Real Hacienda, Libro Copiador, T. 462, fol. 8. Al respecto es primordial la consulta de Toledo, Francisco: Disposiciones gubernativas para el virreinato del Perú (1569-1580), Introducción, Guillermo Lohmann Villena; transcripción, María Justina Sarabia Viejo. Sevilla, Escuela de Estudios Hispano Americanos - Consejo Superior de Investigaciones Científicas, 1986-89, 2 vols. Francisco de Toledo, quinto virrey del Perú (1569-81), llegó para resolver una serie de encargos reales y, en lo fundamental, con el objeto de incrementar a toda costa la producción de plata del Rico Cerro de Potosí y otros lugares del Alto Perú. En su gestión, se destacó por normar y organizar el trabajo indígena a través de la mita, a fin de proteger y garantizar la continua explotación minera.

14 Con relación a los continuos ataques por parte de naves enemigas de Castilla y sus grandes efectos en toda la región del Caribe, para aquellos años, es necesario consultar la exhaustiva investigación realizada por Juárez, Juan: Piratas y Corsarios en Veracruz y Campeche. Sevilla, Escuela de Estudios Hispano Americanos, 1972.

15 Arcila: Economía Colonial, T. I, pág. 105; y del mismo: El régimen, pág. 278. Aun cuando el mes de emisión de esta cédula no coincide con los que Arcila cita en sus dos trabajos, al decir que el Decreto tiene fecha de noviembre y agosto respectivamente, si bien duda, tiene mucha razón cuando dice: "Es muy probable que la decisión de implantar en Venezuela la encomienda de tributo [en dinero] obedeciese a esa sola finalidad". 
años de lo líquido y efectivo que quedare del valor de ellas a los encomenderos, deducidas primero todas las cargas que tuvieren ya que lo que esto importa en el dicho curso de los referidos cuatro años, que han de empezar a correr y contarse desde el día primero de enero de 1688, se vaya enterando y metiendo como fuere cayendo con toda cuenta y razón en la Caja Real de esa ciudad, cuidando vos de que, lo que esto importare, se retenga en ella con toda separación y sin juntarlo con la demás hacienda mía para la aplicación que yo delibere dar a este caudal. ${ }^{16}$

La exigencia de tan urgente contribución se justificaba, en parte, por la misma tradición de esa renta, ya que desde la conquista de las Indias el fin y asunto principal del repartimiento de los naturales por vía de encomiendas, que virreyes y gobernadores en nombre de los reyes hacían merced a particulares por diferentes motivos, se dirigían principalmente a la defensa de aquellos dominios. Así pues, al determinar lo infructuoso de las fuerzas de tierra, sin capacidad siquiera para contener a los enemigos y que sin nuevos destacamentos, armas y naves no podrían disfrutar con toda libertad y seguridad sus haciendas, resultaba conveniente que los encomenderos asistieran al resguardo con sus caudales. Para ello y atento a que la Nueva España, con lo que montaba la mitad de sus encomiendas, no podía acudir sola a la defensa de esa inmensa región caribeña, reservó la media anata de las encomiendas tanto de Venezuela como de otras provincias indianas.

Tocó a Diego Jiménez de Enciso, marqués del Casal, ${ }^{17}$ recibir la cédula para retener la mitad de aquellas rentas líquidas. La orden llegó al puerto de La Guaira el 10 de septiembre de 1688, procedente de los reinos de Castilla y con registro para la provincia, tres días más tarde el nuevo gobernador la mandó publicar en la plaza para conocimiento de los encomenderos y corregidores de indios. ${ }^{18}$ Con el pregón se inició la cobranza del complemento de la renta, que guardarían en las arcas reales de la capital y los jueces de Hacienda no sólo certificarían las pagas que hicieran los corregi-

16 AGN-C, Real Hacienda, Libro Copiador, T. 462, fol. 61vto. Cédula del 2 de septiembre de 1687, al Gobernador y Capitán General de Venezuela.

17 Desde el 24 de abril de 1688 el marqués del Casal ya se encontraba en la capital de Venezuela, ciudad de Santiago de León, provincia de Caracas. Registran los documentos que era pariente del rey, caballero de la orden de Santiago, alcalde mayor de sacas de la ciudad de Sevilla y su Arzobispado, Obispado de Cádiz, Vicaría de Lepe, Ayamonte, Cartaya y La Redondela, alcaide perpetuo del castillo de la Salobreña y ahora, ejerciendo los oficios de gobernador y capitán general de Venezuela, nombrado por el rey.

18 AGN-C, Real Hacienda, Libro Copiador, T. 462, fol. 59vto. Auto del 11 de septiembre de 1688 , donde el gobernador y capitán general de Venezuela manda retener la mitad, ya líquido, de la renta que perciben los encomenderos por concepto de indígenas encomendados. 
dores, sino que la ingresarían por cuenta aparte y sin mezclarla con otro arbitrio real.

En adelante, el gobernador despachó copias de la cédula, junto con autos suyos, para que sus tenientes las publicaran en todos los pueblos de la tierra adentro, a fin de que los corregidores entregaran puntualmente lo que montara la media anata líquida y los administradores fiscales, cada uno en su jurisdicción, asentaran el producto por separado. De igual forma procederían los oficiales de la caja de Caracas en cuanto a la razón del cargo y descargo de la renta que, sin ligarla ni retardo, remitirían lo que montara en cada año, como estaba dispuesto, pena de que se despacharía persona a su costa para cumplir con la remisión hasta su destino. El 16 de septiembre se hicieron las diligencias ante los jueces de Hacienda para que observaran lo mandado y no fue hasta el 26 de noviembre cuando la cédula se asentó en los libros de la Tesorería.

Entre los pliegos reales que arribaron al puerto de La Guaira por junio de $1691,{ }^{19}$ reexpedidos desde el puerto de San Juan de Ulúa (Nueva España) en la fragata del capitán Juan Martínez de Laspidea luego de transportar el azogue desde Castilla, el gobernador recibió una nueva cédula, fechada en Madrid por septiembre de $1690 .{ }^{20}$ Se trataba de la respuesta a ciertas dudas elevadas ante el Consejo de Indias, tanto por vecinos de Venezuela como de otras provincias americanas, acerca de si las pensiones se incluían o no en el descuento de la media anata. Tras ratificar lo ordenado en septiembre de 1687, sobre la cobranza y su forma de recaudar, el rey resolvió que en las "pensiones" se observara lo mismo que en las "encomiendas", por constituir un mismo principio tanto en su origen, como en la obligación por parte de quienes las gozaban para defensa de las Indias, de suerte que contribuyeran durante los cuatro años con la mitad de lo que últimamente percibían. No obstante la regla, quedaron exentos encomenderos y pensionarios que no obtuvieran 200 pesos útiles de renta y para cuya regulación se ajustó a lo que pagaran por el derecho de media anata, en orden al efectivo valor de las encomiendas que gozaran o de las pensiones situadas en ellas.

Mandaba el monarca en esa oportunidad que el caudal procedido se destinara para la fábrica de armamento y navíos, nuevamente establecidos en Nueva España y hasta donde viajaba el conde de Galve con el alto oficio para regir el virreinato y encargarse de tal empresa. Para procurar el

19 Ibídem, fols. 79-79vto. Auto del 8 de junio de 1691, dictado por el gobernador y capitán general de Venezuela.

20 Ibídem, fols. 79vto.-80. Cédula del 17 de septiembre de 1690, al marqués del Casal. 
envío de los efectos, el virrey comunicó al gobernador la comisión real y que advirtiera lo propio a los oficiales de Hacienda, en cuyo poder estaban los recursos que a propósito se emplearían en el castigo y extinción de los piratas que infestaban aquellas costas. En tal sentido, el rey le indicaba al marqués del Casal:

déis las ordenes convenientes para que por los dichos cuatro años, se cobre la media anata en toda esa provincia así de las encomiendas como en las pensiones, exceptuando como se ha dicho a los encomenderos y pensionarios que no gozan útiles 200 pesos de renta, disponiendo su cobranza y entero en mi caja y para que mi virrey de la Nueva España pueda ir obrando en cuanto al armamento, lo que se ha de ejecutar. ${ }^{21}$

Tan pronto como se ordenó continuar con los términos del instructivo, Joseph Ramírez de Arellano, procurador general de Caracas y en nombre de los vecinos afectados de la provincia, suplicó al rey la anterior medida, en cuanto a proceder con el cobro complementario a que estaba sujeta la media anata y, en particular, las encomiendas y pensiones. Proponía el apoderado que se elevara el monto de la dispensa y cuya renta sólo se aplicara a quienes obtuvieran 500 pesos útiles, restituyendo lo que por esta razón, se sustrajo a los encomenderos y pensionarios o sus herederos. Petición que no consiguió los resultados esperados, pues una cédula fechada en Madrid por septiembre de 1691 y dirigida al marqués del Casal expresaba la voluntad real:

déis pronto cumplimiento en esa provincia a lo dispuesto a cerca de esto, en el despacho citado de 17 de septiembre de 1690, dando la orden necesaria, para que se restituya (en caso de haberse cobrado) a los encomenderos y pensionarios o a sus herederos que no gocen útiles 200 pesos de renta lo que por esta media anata se les hubiese desfalcado en estos cuatro años, ejecutándose esta restitución de los medios que hubiere en mis Cajas Reales, procediendo de lo percibido y cobrado de la media anata de estas encomiendas y pensiones y si no los hubiere, pronto se haga de lo que se fuere cobrando de esta misma imposición hasta satisfacer enteramente a los encomenderos y pensionarios que por esta razón se les hubiere desfalcado. ${ }^{22}$

Por octubre de 1692, el entrante gobernador Diego Bartolomé Bravo de Anaya recibió su primer despacho regio, y por él, tras ratificar la anterior cédula, se le ordenaba "lo que se ha de ejecutar en la cobranza de la media anata de las encomiendas con los sujetos que no ganaren útiles 200 pesos de renta". ${ }^{23}$ Para cumplir con tal cometido, mandó que se publicara

21 Ibídem, fol. 81.

22 Ibídem, fol. 122vto. Cédula del 18 de septiembre de 1691, al marqués del Casal.

23 Ibídem, fol. 121vto. Auto del 17 de octubre de 1692, del gobernador y capitán general de Venezuela, Diego Bartolomé Bravo de Anaya. 
en la ciudad a toque de "caja de guerra" y hecho se llevara ante los oficiales de Hacienda para que tomaran la razón. El día 29, de nuevo se pregonó en la plaza y otras partes públicas.

\section{Reformas introducidas en la tributación}

Después de casi siglo y medio, tiempo durante el cual los vecinos de Venezuela usufructuaron la encomienda de "servicio personal", las viejas intenciones de la Corona por modificar la antigua forma de tributar a que estaban sometidos los indígenas de la provincia desde los primeros años de la colonización, se concretaron hacia la penúltima década del siglo XVII.

No fue hasta 1687, a raíz de la visita que la Corona ordenó sobre las Cajas de la Real Hacienda de Venezuela, cuando en la provincia se inició una profunda revisión del sistema que explotaba el trabajo indígena y que concluyó con su inmediata transformación. Los intereses fiscales se llevaron a cabo mediante la gestión mancomunada del gobernador y el obispo, tras acogerse a las cédulas que ponían fin al servicio personal. A partir de ese año, los indígenas quedaron obligados a tributar anualmente en "dinero" o su equivalente en especie que entregarían a los corregidores nombrados para tal efecto y cuya normativa provincial, dependiendo de los pueblos indígenas respecto a Caracas, estableció los montos del tributo y su distribución para financiar el sueldo del corregidor y la contribución a las cajas de comunidad. Pero con ello, también se modificaron y reajustaron las asignaciones que por concepto de estipendios recibían los curas doctrineros tras las gestiones del gobierno religioso y, que desde entonces, dependieron de las tasas que se impusieron como tributo a los indígenas. ${ }^{24}$

24 Mucho se ha publicado sobre la materia en Hispanoamérica y para ello recurro de nuevo al trabajo de compilación bibliográfica de Hidalgo H. y Mudarás G.: La Encomienda, págs. 52-61. Con un registro de 116 títulos sobre "tributación indígena" para la época colonial en América y Filipinas, donde incluye artículos pioneros desde los años 20 y 30 hasta los 90, casi el $45 \%$ de esa producción intelectual corresponde a las últimas dos décadas del siglo XX y, en particular, la de 1990 se anotó el 23,28\% del total. Sin embargo, para Venezuela escasamente señala tres trabajos (2,59\%). Entre estos tenemos: Sucre Reyes, José: "El sistema tributario durante la época colonial”, Boletín de la Cámara de Comercio de Caracas, N. ${ }^{\circ}$ XXX, Caracas, 1942; Río, Mercedes del: "La tributación indígena en el repartimiento de Paria (Siglo XVI)”, Revista de Indias, N. ${ }^{189}$, Madrid, 1990, págs. 397-429; Nestares Pleguezuelo, María José: "Tributación indígena y déficit fiscal en la Nueva Andalucía durante el siglo XVIII", en María del Carmen Mena García (Coord.), Venezuela en el Siglo de las Luces, Sevilla Bogotá, Muñoz Moya y Montraveta editores, 1995, págs. 173-200; y Rosas González, Otilia: El tributo indígena en la provincia de Venezuela, Caracas, Historiadores Sociedad Civil, 1998. 


\section{Cambios en los pagos de la tributación}

\section{El interés fiscal de la Corona}

El primero de marzo de 1687 llegó al puerto de La Guaira el Dr. Diego de Baños y Sotomayor, no sólo como obispo electo para Venezuela, ${ }^{25}$ sino que además, por los documentos y credenciales presentados ante el gobernador y capitán general, los jueces oficiales de Hacienda y restantes autoridades de la Justicia y Regimiento del Cabildo seglar, a nivel local, demostró venir por especial comisión del rey como juez visitador de las cajas reales de la provincia. No fue hasta febrero del siguiente año, cuando por un auto el obispo justificó las precisas ordenes que traía en materia fiscal y, sobre todo, en tratar de aplicar lo que se mandaba por el recién compendio de Leyes, ${ }^{26}$ como era, cobrar por el arancel de la media anata todas la mercedes, títulos, oficios y rentas que se dieron en la provincia; no obstante, por la restante información, quedaban evidentes otros sutiles intereses de la Corona.

La visita del obispo a las Cajas se practicaría sin interferir con la gestión del gobernador, pues, aun cuando el prelado se destinaba a revisar los libros de la oficina de contaduría con el fin de comprobar las cuentas que entregaron los anteriores oficiales de Hacienda, no sólo se destacaba en ella la cobranza de la media anata, sino también indagar sobre las comisiones que el gobernador y los tribunales dieron a personas extrañas para atender los negocios de la Corona en la región, ya que en aquellos libros:

no consta ni aparece haber cobrado el real derecho de media anata de los jueces de Residencia y subdelegados de ellos, que han venido a esta dicha provincia a tomarla a sus gobernadores como ni tampoco de los jueces de comisión que se despachan a las ciudades de ella con salarios, por no haber puesto en estilo ni acostumbrado en los tiempos antecedentes, en lo cual ha sido y es damnificado gravemente el Real Haber en cantidades considerables. ${ }^{27}$

La Junta de Media Anata extendió el cobro de este derecho, dispuesto en su forma por arancel y resoluciones, hasta los oficios de corregidores

25 El Dr. Diego Baños y Sotomayor era miembro del Consejo del Rey, su predicador y capellán de honor. En la época se decía que fue nombrado por la gracia de Dios y de la Santa Sede Apostólica como obispo de Caracas y Venezuela; antes lo fue de Santa Marta.

26 En este caso, se refiere al pronto cumplimiento de la Recopilación de las Leyes de Indias, Madrid, 1680; como se aprecia, tan sólo impresa unos cuantos años antes.

27 AGN-C, Real Hacienda, Libro Copiador, T. 462, fols. 41vto.-42. Auto del 3 de febrero de 1688 , dictado por el obispo de Venezuela, Diego Baños y Sotomayor. 
que proveyeran los virreyes, presidentes y gobernadores. Pero la misión del obispo, quizás no tan interesado por la estricta pesquisa fiscal ante los escasos rendimientos económicos, se dedicó a reordenar la precaria situación creada con los nombramientos que realizara el gobernador Diego Melo Maldonado, respecto a los "diferentes corregidores de los pueblos de indios de la jurisdicción de cada ciudad y señalándose renta en cada un año por demorarse las que hay en ella". ${ }^{28}$

En tal sentido, mandó el ilustrísimo obispo a los jueces oficiales de Hacienda que ellos y sus tenientes, a cuyo cargo estaba la Caja principal en Caracas y las restantes cajas sufragáneas en las ciudades de la tierra adentro, cobraran desde el 3 de febrero en adelante el derecho de media anata tanto a los jueces de residencia, los subdelegados y demás personas que se despacharon con salarios y por jueces de comisión a las ciudades de la provincia, como también a los corregidores y administradores de los pueblos de indios nombrados por el gobernador, aunque fueran interinos.

\section{Fin del servicio personal y la nueva tributación}

Desde finales del siglo XVI y con más ardor durante el XVII la monarquía tenía mandado por repetidas cédulas y ordenes dirigidas a los diferentes gobernadores de Venezuela, que entendieran sobre la supresión del servicio personal y en lo posible resolvieran sobre los grandes perjuicios a que estaban sometidos los indígenas y les seguirían de continuar con la forma de tributar en servicio, procedimiento impuesto desde antiguo en esa provincia. ${ }^{29}$ Sin embargo, hasta entonces fue tarea de los cabildos así como función de los procuradores de las ciudades el de apelar ante el rey para refutar tales criterios y, sobre todo, contando con el apoyo de las continuas peticiones hechas por los vecinos desde sus corporaciones, los procuradores de Caracas asumieron el compromiso en nombre de la gobernación para luchar por aquellos antiguos privilegios. Así pues, cada vez que la Corona emitía leyes en este sentido, de inmediato los negociadores enviados a la Corte le salían al paso con otros tantos ruegos, con lo cual lograban que el monarca consintiera temporalmente el servicio personal o en su defecto ganaban especiales mercedes para que la tributación conti-

28 Ibídem, fol. 42.

29 Arcila: Economía Colonial, T. I, pág. 60; del mismo: El régimen, págs. 196-201, 213, 217. 
nuara sin ninguna variación; ${ }^{30}$ pero los reyes nunca abandonaron su defensa y protección.

Vicisitudes que no se definen hasta mediados de 1687, cuando en atención a los reales mandatos y, en concreto, por la cédula del 26 de agosto de 1686 que le ponía fin a tal sistema, por autos del gobernador, se tomaron las primeras medidas para eliminar el servicio personal y con ello establecer una nueva modalidad. Pero la idea no era tan reciente, pues sólo se trataba de aplicar la ya mañosa figura de la "demora"; con ella, los indígenas cesaron en la obligación de prestar servicio personal a sus encomenderos, y en lo sucesivo, quedaron obligados a dar un tributo anual, mientras la fuerza de trabajo se comenzó a contratar por el encomendero como empresario agrícola. ${ }^{31}$ Desde esta fecha, el modelo consagró que los indígenas de la provincia encomendados o en cabeza de la Corona, tributaran únicamente en dinero efectivo o su equivalente en especie a partir tanto de los frutos cultivados como del trabajo remunerado. ${ }^{32}$ No obstante, será necesario que tales arreglos esperen hasta el $1^{\circ}$ de agosto, pues en esa oportunidad y tras el unánime acuerdo e inmediata orden de las máximas autoridades regionales, constituidas en este caso por el gobernador y capitán general, marqués del Casal y el obispo, Dr. Diego de Baños y Sotomayor, cuando finalmente y en tanto el rey no mandara otra cosa, los indígenas fueron puestos en libertad:

quitándoles y aliviándoles del servicio personal que pagaban a sus encomenderos, de tres días cada semana, quedando como los indios de toda esta América con la obligación de tributar un año lo que pareciere conveniente y se les señalase, que entonces fue a razón de doce pesos y cuatro reales en cada un año de tributo. ${ }^{33}$

30 Cuestión que recoge en su trabajo Arcila Farías, Eduardo: Hacienda y Comercio de Venezuela en el Siglo XVII: 1601-1650. Caracas, Banco Central de Venezuela, 1986, Vol. V.

31 Arcila, El régimen, págs. 264-265.

32 Señala Nestares, para la provincia de Cumaná, que por cédula del 26 de agosto de 1686, "se ordenaba al gobernador que eliminase el servicio personal de los indios encomendados, y los demorase para que a partir de ese momento su obligación quedase reducida al pago a sus encomenderos del tributo que se les señalase y no volviesen a entregar su trabajo como obligación". Nestares, “Tributación Indígena", págs. 180-181. Pero no fue hasta 1712 cuando el nuevo sistema de tributación indígena comenzó en aquella provincia.

33 AGN-C, Real Hacienda, Libro de la Concordia que señala los estipendios que anualmente gozan los curas doctrineros de esta provincia de Caracas, formada el 6 de junio de 1691. Caracas, 1691, T. 30, fol. 5vto. El maestro Arcila declara no conocer la Cédula sobre la nueva reglamentación, sino el testimonio del teniente de gobernador de San Carlos de Austria, jurisdicción de Caracas, cuando se leyó el mandato del gobernador. Arcila: El régimen, pág. 218; pero tampoco manejó el Libro de la Concordia, pues en ningún momento lo cita y nunca hizo referencia al mismo. 
Poco después se remitieron a Venezuela dos nuevos despachos reales: uno del 30 de septiembre de 1688 y ratificado por otro del 17 de noviembre del siguiente año, donde, luego de alegar su católico y piadoso celo, el rey mandaba que se rebajaran los anteriores montos hasta 6 pesos a los que vivieran en la jurisdicción de las diez leguas en contorno de Caracas; y 4 pesos a los que habitaran en la tierra adentro. A ello se le sumaban: 4 reales que tomaría para sí el corregidor y que percibiría por su salario; más otros 2 reales para las arcas de comunidad; más lo que tocara por gastos de doctrina y estipendios. Montos que pagarían los indígenas adultos de 18 a 50 años en dinero, géneros o frutos y que entraba a ejecutarse de inmediato, en espera de que el rey ordenara otra cosa. ${ }^{34}$

Por los testimonios y autos que continuaron presentándose ante el Consejo de Indias, suplicando la confirmación de nuevas encomiendas, se puede observar que mientras el rey confirmaba las mercedes hechas por el gobernador y las aprobaba mediante los correspondientes títulos expedidos, dejó constancia que a partir de entonces, todos los beneficiarios de encomiendas quedaban exceptuados "de dar medio real a cada indio que trabajare en vuestra hacienda, porque esta la revoco y anulo". ${ }^{35}$ Asunto que observaron puntualmente, como también lo ordenado por los anteriores despachos de 1688 y 1689, cuando se ajustó con moderación tanto la tasa y tributo que pagaría cada indígena como la forma en que, en adelante, contribuirían. ${ }^{36}$

\section{Disposición de la tributación indígena}

Las originales órdenes sobre la tributación indígena las recibió el marqués del Casal por enero de 1691. De acuerdo al regio mandato y por su autoridad, el gobernador dispuso en forma reglamentaria la inmediata aplicación de las nuevas condiciones que regirían el sistema de tributación. ${ }^{37} \mathrm{La}$ instrucción establecía que por los tercios del año se cobrara a cada indíge-

34 Arcila, El régimen, pág. 267.

35 AGN-C, Real Hacienda, Libro de la Concordia, T. 30, fol. 6.

36 Anulación que se apresuraron a guardar y así se aprecia en las cédulas sobre la confirmación de encomiendas dirigidos, por ejemplo, al sargento mayor Luis de Silva y Piña (1689, diciembre); Bartolomé Pan y Agua de Trexo (1689, diciembre); y Alonso Moxica Santillán (1690, diciembre). AGN-C, Real Hacienda, Libro Copiador, T. 462, fols. 107-107vto.; 109-109vto.; 120vto.-121.

37 AGN-C, Real Hacienda, Libro Copiador, T. 462, fols. 83-84. Auto del 8 de enero de 1691, dictado por el marqués del Casal. 
na útil comprendido entre los 18 hasta los 50 años de edad la obligación que el rey les especificara. En tal sentido, pagarían anualmente 6 pesos de ocho reales los indígenas de los pueblos de Caraballeda, El Cojo, Macuto, Maiquetía, Mamo, Naiguatá y Torrequemada, por ubicarse dentro las 10 leguas cercanas a la ciudad de Santiago de León; mientras los pueblos de Cagua, Curiana, Santa Cruz y Tarmas pagarían 4 pesos de a ocho en cada año, por estar fuera de las 10 leguas de aquella jurisdicción. Tributo que entregaría cada indígena en las porciones señaladas y según la distancia, tanto por el derecho que pertenecían al monarca mientras estaba bajo su administración, como por lo que debía el encomendado a su encomendero. Cantidades a las que se debían sumar los ya referidos 4 reales para el corregidor y 2 reales más para las cajas de comunidad. Todo lo cual montaría, para los pueblos dentro de los límites de las 10 leguas de la Capital, 54 reales y a los que estuviesen fuera de ella, 38 reales sencillos por cabeza en ambos casos. ${ }^{38}$

Hacia julio de 1692 y a escasas semanas de arribar a la provincia, tocó al recién nombrado gobernador, Dr. Bravo de Anaya ${ }^{39}$, poner en marcha las órdenes para estrenar el nuevo gobierno de los indios tributarios. Por auto de esa fecha, y en cumplimiento de un pliego real del 12 de diciembre de 1691, se le ordenaba que diera forma a dos tareas: en principio, recaudar la demora del tributo que debían pagar los naturales de su circunscripción; luego, organizar el gobierno político a que estarían sometidos los indígenas. Aun cuando existían otras cuestiones menores, tan sólo eran circunstancias contenidas en la propia cédula. Para su pronta ejecución el gobernador no sólo mandó que el decreto se pregonara en la capital, sino, además, que se despacharan mandamientos a los alcaldes ordinarios de todas las ciudades de la tierra adentro, para que igualmente cada uno lo publicara en la cabecera de su distrito. ${ }^{40}$

No será sino a partir del siguiente mes y en atención a la anterior cédula, respecto a guardar la recaudación de los indígenas tributarios, cuando el gobernador comenzó a remitir los explícitos despachos a los alcaldes

38 Ibídem, fols. 83-83vto.

39 El 31 de mayo anterior llegaba a Caracas el Dr. Diego Bartolomé Bravo de Anaya, miembro del consejo real y quien era, además, alcalde de la corte real así como oidor de la Audiencia y Chancillería de la ciudad de Santo Domingo de la isla Española. Nombrado por el rey, venía como juez de comisión para la provincia y a cuyo cargo estaría su inmediata dirección con los títulos de gobernador y capitán general de Venezuela.

40 AGN-C, Real Hacienda, Instrucción de Corregidores y Tasas de Tributos de Indios. Caracas, 1694, T. 32, fol. 47. Auto del 14 de julio de 1692, ordenado por Bartolomé Bravo de Anaya, gobernador y capitán general de Venezuela. 
ordinarios de las ciudades interiores. Al dirigirse, por ejemplo, a las autoridades locales de la Nueva Valencia del Rey, ${ }^{41}$ tras informar sobre la precedente cédula del 12 de diciembre, les ordenó lo que observarían sobre el nuevo gobierno de los naturales y que al presente se hallaban demorados. Por el auto, el gobernador estableció dos propósitos: en cuanto a su puntual obediencia, que se publicara en la ciudad y de inmediato advirtieran sin omisión alguna a los corregidores de los pueblos indígenas de aquella jurisdicción, con el fin de entregar los testimonios para su mejor desempeño y gobierno; y con relación a los indígenas, que sin dilación procedieran a matricular todos los naturales de sus partidos con claridad y distinción, como más largamente aparecía en la cédula y autos remitidos.

La idea de cursar orden a los alcaldes ordinarios se explicaba, en parte, primero por su competencia en la materia y, luego, como autoridad local para que la ejecutaran y vieran su riguroso cumplimiento a la vista de los corregidores. Sin embargo, dos años más tarde, todavía el gobernador alertaba, ${ }^{42}$ que si bien por autos de su antecesor constaba el despacho de las instrucciones a los distintos funcionarios, hasta la fecha no remitían noticia que certificara la publicación de aquella cédula (con excepción del capitán Bartolomé de Torrealva Errus y Sotomayor, alcalde de El Tocuyo). Por tal omisión, los alcaldes ordinarios de 1692 fueron penados en 25 pesos para la fábrica de la cárcel de Caracas, en tanto a los que ejercían el cargo y al tiempo que se les notificaba que dentro de los siguientes 20 días mandaran certificación, con igual pena de no cumplirlo, se les cursaba la disposición con la instrucción y autos para que los llevaran a cabo dentro del término.

Por enero de 1694 entró en la ciudad de Santiago de León el maestre de campo, Francisco de Berroterán, cuyos títulos de gobernador y capitán general de Venezuela se le concedieron en junio de $1692 .{ }^{43}$ En ellos si bien se repiten las antiguas órdenes sobre el buen cuidado y conservación del indígena, también se le subraya la conducta a seguir especificándose que por las infracciones que cometiera sería juzgado en la residencia con imposición de las pertinentes penas. Al resumir las obligaciones sobre este asunto, resaltan: 1) cuidar el buen trato al indígena durante las visitas ordinarias u otras comisiones al interior, no despojándole sus provisiones ni animales

41 Ibidem., fols. 16-17. Auto del 27 de agosto de 1692, despachado por el Dr. Bravo de Anaya.

42 Ibídem, fols. 5-5vto. Auto del 22 de enero de 1694, ordenado por Francisco de Berroterán, gobernador y capitán general de Venezuela.

43 AGN-C, Real Hacienda, Libro Copiador, T. 462, fols. 130-130vto. Cédula del 9 de junio de 1692, al maestre de campo Francisco de Berroterán, caballero de la orden de Santiago, por la cual se le nombra Gobernador y Capitán General de Venezuela. 
de sustento y siendo voluntario pagar justamente el costo, según la estimación del común precio y evitando así cualquier perjuicio o vejación; 2) la obligación de empadronar los indígenas tributarios, tras encargarse del gobierno, como lo dispusiera por ordenanza Francisco de Toledo, virrey del Perú y luego confirmada por provisión real; 3) cobrar los tributos a los indígenas de su distrito pues de no hacerlo pagaría con su patrimonio por los "rezagos" que se causaran, mientras sobre los "tributos" sufragarían sus fiadores lo que dejara de cobrar; y 4) observar la prohibición de no tocar las cajas de comunidad por ningún motivo, ni siquiera para servicio de los indígenas y menos ocupar su dinero en actividades particulares.

No estarían muy adelantadas las diligencias administrativas, mandadas con tanta insistencia por el rey desde Madrid, cuando el gobernador Berroterán, a consecuencia de lo ordenado en sus credenciales y, en particular, por la ya indicada cédula de diciembre de 1691, decide promulgar con fecha 9 de febrero de 1694, la Instrucción que formó tanto para el funcionamiento y gobierno de los pueblos de indios, como para el trabajo de los mismos y por la cual, en adelante, comenzaron a regirse los corregidores de toda la Provincia. ${ }^{44}$ Por una cédula fechada en El Buen Retiro, a 17 de junio de 1696, el rey se sirvió aprobar y mandar que se obedecieran los 40 capítulos contenidos en la Instrucción General que por febrero de 1694 se formara para el gobierno de los Corregidores de Indios de Venezuela. Pero el veredicto confirmatorio de aquella ordenanza, finalmente llegó a la ciudad, entre los despachos que recibiera el gobernador, por diciembre de 1697.45

\section{Reajustes en los estipendios a doctrineros}

\section{La asignación de estipendios}

Por costumbre y de conformidad con los antiguos mandatos reales, siempre y cuando fuera necesario señalar el estipendio de los curas, el habitual estilo empleado se expresó a través del mutuo acuerdo o "concordia"

44 AGN-C, Real Hacienda, Instrucción de Corregidores, T. 32, fol. 1. A manera de título, se lee en el encabezamiento del documento: "Instrucción formada el año de 1694 para el gobierno de los indios y sus corregidores de esta provincia de Venezuela, su Capitán General y Gobernador, el Maestre de Campo don Francisco de Berroterán". Por otra parte, Nestares nos refiere que el gobernador de Cumaná, Ramírez de Arellano, hacia 1700 formó una Ordenanza Municipal con 41 artículos para regular el funcionamiento, gobierno y trabajo de los pueblos indígenas. Nestares: "Tributación Indígena", págs. 177-178.

45 Ibídem, fol. 39. Auto del 11 de diciembre de 1697, ordenado por Francisco de Berroterán. 
entre el Prelado Eclesiástico y el Vicepatrono de cada entidad administrativa. En tal sentido y ante la demanda de lo que se establecía ya por las cédulas y órdenes del monarca ya por los autos del gobernador en razón de la demora que se impuso por agosto de 1687, cuando los indígenas de Venezuela si bien entraron a gozar de la libertad del servicio personal, con igual rigor cesó la forma y modo que hasta entonces se observó tanto en la satisfacción de los estipendios de los curas doctrineros, como en el pago de otros sueldos y pensiones asignadas en las encomiendas. El anterior régimen corría desde la primitiva tasa general que en 1609 se dispuso por acuerdo del reverendo maestro fray Antonio Alcega y Sancho de Alquiza, gobernador y obispo que fueron de la provincia de Venezuela. ${ }^{46}$

En el Sínodo Diocesano que por aquellos años celebró en Caracas el ilustrísimo Alcega y donde confirmó la antigua tasa, también se estableció que estaba a cargo de los encomenderos el proveer las iglesias de los pueblos indígenas con los ornamentos sagrados y otras cosas necesarias tanto para el culto divino como para la administración de los Santos Sacramentos. Pero desde 1687 y por ser inexcusable la decoración religiosa, siempre que faltara, se mandó que los frailes lo suplieran a expensas de los efectos que tributaran los indígenas del pueblo donde estuviera la iglesia y alcanzara el partido. En tanto, el cura doctrinero daría recibo a la persona a cuyo cargo se hallara la cobranza de los tributos, arreglándose en esto a las leyes y cédulas expedidas para tal efecto.

Por otra parte, y según como se observara hasta ese primer día de agosto, cuando cesó el servicio personal y con ello acabó la obligación de los encomenderos, los estipendios y pensiones comenzaron a pagarse por la Real Hacienda con lo que tributaban los indígenas. Así lo tenía dispuesto la monarquía a través de diferentes leyes y en particular, por la Recopilación de las Leyes de Indias, en donde se mandaba que a los doctrineros con 400 indígenas tributarios, se les acudiera anualmente para su congrua y sustentación con 50.000 maravedís. De este modo, el obispo y gobernador ratificaron el tradicional monto que señalaron en la tasa general, mientras en la particular, hecha para los estipendios de los curas doctrineros, mandaron añadir que los encomenderos diesen a cada doctrinero dos fanegas de maíz

46 AGN-C, Real Hacienda, Libro de la Concordia, T. 30, fols. 6-6vto. La incertidumbre que presionaba sobre el servicio personal no sólo encontró un cierto alivio cuando se dictaron las Ordenanzas de 1609, sino que en adelante esta normativa consolidó el sistema de servicio personal como forma de explotar la fuerza de trabajo indígena. Sobre estas Ordenanzas dijo el Dr. Arcila, por desconocer el Libro de la Concordia, que "se mantuvieron en vigencia hasta la extinción de la misma encomienda impuesta por decreto en 1718”. Arcila, El régimen, pág. 208. 
al mes para el sustento así como lo necesario para vino, cera y hostias con que celebrar y ocho reales por misa de cada indígena que muriera. ${ }^{47}$

\section{Imposición de nuevas tasas}

Con el fin de examinar las nuevas condiciones del tributo indígena y conferir lo más conveniente, al efecto de tasar y señalar el estipendio que en adelante percibirían los curas doctrineros de los pueblos indígenas, se reunieron en la ciudad de Santiago de León, provincia de Caracas, Diego Jiménez de Enciso, marqués del Casal, gobernador y capitán general y el ilustrísimo Diego de Baños y Sotomayor, obispo de la diócesis, ambos de Venezuela. Visto lo que se ofrecía y por unánime acuerdo, el 6 de junio de 1691 firmaron un documento que llamaron Testimonio de Concordia. ${ }^{48}$

A la letra del concierto alcanzado por las superiores autoridades en lo civil y eclesial, mientras establecían un nuevo orden de pagar los estipendios, renovaron las tasas tanto para el buen gobierno administrativo, como para que cada religioso conociera el salario que le tocaba. La práctica de reajuste se basaría en las matrículas que el mismo gobernador ordenó hacer entre las encomiendas correspondientes a la jurisdicción de cada partido. Así ocurrió con los registros indígenas ya levantados para los términos de Caracas, Coro, Barquisimeto y Valencia, en tanto se realizaban las que tocaban a las demás localidades de la jurisdicción gubernativa.

Por las cuentas que el gobernador tenía en sus manos, como eran las referidas a los tributos recaudados entre los indígenas de Caracas y Valencia, las propias autoridades reconocieron que, por las diferentes condiciones económicas existentes entre algunos partidos y doctrinas, no se podía ajustar a todos los curas por igual con el estipendio de 50.000 maravedís, más lo estimado para maíz, vino, cera y hostias, pues, ante el corto número de indígnas asignados, lo que producían sólo alcanzaba para una tenue contribución. En todo caso y aunque se entregara todo el tributo a los doctrineros, sin reservar nada para ornamentos y satisfacción de las pensiones que el rey impusiera para la cátedra de gramática de Caracas y los soldados del puerto de La Guaira, nada les quedaría a los encomenderos. Por lo ya visto y comprobado, se estableció que:

47 Ibídem, fols. 6vto.-7.

48 Ibídem, fol. 1. Testimonio de Concordia, celebrado en esta Capital el 6 de junio de 1691. 
no se puede regular igualmente, a punto fijo el dicho estipendio, por haber en unos pueblos y partidos más indios que en otros y haber crecido el número de los indios en algunas poblaciones y otras minorándose con el transcurso del tiempo, de manera que en los partidos que antiguamente tenían los doctrineros el estipendio y meses de doctrina enteros, ahora no alcanza ni aun a la mitad, y en otros que tenían muy corto estipendio y pocos meses de doctrina, ahora se les puede asignar enteramente, según se ha visto y reconocido por la razón que se halló en la Real Contaduría de lo que percibían los dichos curas doctrineros, en conformidad de la dicha tasa antigua. ${ }^{49}$

Si bien estas fueron suficientes razones para que las autoridades llegaran a la concordia, la necesidad de nuevas tasas y orden administrativo se orientaba hacia el buen gobierno sobre la materia, sobre todo, porque además convenía que las personas a cuyo cargo estaba el percibir los tributos y satisfacer los estipendios supieran lo que se le pagaría fijamente a cada doctrinero. A fin de cumplir con las cédulas, ordenes, autos, matrículas y demás recaudos presentados y para que quedara asentado lo que se cumpliría en adelante, el obispo y el gobernador asignaron temporalmente lo que encontraron más conveniente y tasaron:

para estipendio de cada cura, los 50.000 maravedís que Su Majestad tiene asignados particularmente en todas las doctrinas de esta Provincia, en donde los tributos según el número de indios útiles alcanzaren para esta satisfacción, no obstante que no llegue el número de feligreses a 400 indios tributarios, como en efecto no hay partido que llegue a dicho número. ${ }^{50}$

La anterior observación es pertinente, pues sin ánimo de violar la ley, ${ }^{51}$ la situación se explica por dos hechos: de una parte, ante la escasa concentración indígena y porque muchas doctrinas se componían de dos, tres y más pequeños poblados, muy distantes unos de otros y extendidos por una "tierra doblada, áspera y de penosos caminos"; y de la otra, porque además era difícil agregar a cada doctrina nuevos pueblos y menos cuando se trataba de naciones distintas, aun cuando privara entre los vecinos el sólo afán de llegar al número establecido. ${ }^{52}$ Esta última práctica ya prohibida por

49 Ibídem, fols. 7vto.-8.

50 Ibídem, fol. 9.

51 La referencia de no alcanzar los 400 indígenas tributarios por doctrina no era causa justificable para faltar a la administración de los Santos Sacramentos, buena doctrina y apoyo espiritual, que con tanta insistencia encargaba el católico celo del rey.

52 Con la desaparición del servicio personal e iniciada la demora del tributo indígena, que desde entonces se extendió hasta los más apartados lugares, en los registros para matricular o empadronar aquella población surgió de inmediato y se generalizó una nueva figura de clasificación, como fue la de los "indios agregados". AGN-C, Real Hacienda, Libro de la Concordia, T. 30, fols. 24-26. 
los grandes inconvenientes que experimentaban los indígenas y hasta por acaecer la muerte de algunos naturales tanto por las riñas y ataques entre ellos como por la mudanza en el temple de un territorio a otro.

Por la Concordia las máximas autoridades en lo político y religioso finalmente establecieron una amplia y renovada normativa. Reglamentación que observarían, por aquellos años de aplicación transitoria, mientras el rey dispusiera lo más conveniente, a propósito y conforme con los testimonios e informaciones que le enviaran tanto el obispo como el gobernador, en base a los cuales ordenaría qué hacer en adelante..$^{53}$ Las autoridades también declararon su preocupación, con relación a los inconvenientes y daños espirituales que pudieran aumentar entre los indígenas, de no mantenerlos durante todo el año con la asistencia de la religión y la santa fe cristiana.

El convenio contemplaba además, en cuanto a las doctrinas que no alcanzaran el estipendio de 50.000 maravedís, ya fuera por el corto número de tributarios o por no producir lo suficiente para su satisfacción, que los religiosos percibieran lo señalado según una regulación por meses. No obstante, al considerar que dicho monto sólo alcanzaría para la congrua, sustentación y vestuario de los curas, fue necesario añadirles otra porción anual para comprar vino, cera y hostias con que celebrar en sus iglesias, según estaba dispuesto por la antigua tasa. Para tal efecto fijaron 24 pesos al año, cantidad en que se reguló tan forzoso gasto, según el excesivo precio que en la provincia tenía el vino y la cera, pues eran géneros introducidos desde Castilla. Otro tanto ocurría con las dos fanegas de maíz, que hasta la fecha pagaban los indígenas cada mes para el sustento de los doctrineros. ${ }^{54}$ Luego de reconocer lo corto de sus tributos y sin perjudicar el derecho adquirido por los curas, el gobernador ordenó suspender la tradicional práctica con que éstos percibían las primicias sobre las sementeras.

A condición de lo anterior, los doctrineros no cobrarían nada sobre los tributos ni a los indígenas por razón de bautismos, casamientos, velatorios y entierros, ni con pretexto de obvenciones y derechos parroquiales. Sólo percibirían lo que les tocara conforme al arancel, ${ }^{55}$ como era: por la limosna

53 Ibídem, fols. 9vto.-13.

54 El sustento de los curas doctrineros por los indígenas no sólo fue de uso corriente en Venezuela, sino que la práctica se encontraba muy extendida por todas las doctrinas que en los reinos de las Indias se reputaban en "libertad".

55 Con excepción de los Capuchinos, quienes entre 1691-92 y por faltar los doctrineros, actuaron interinamente en los pueblos de Acarigua, Cerrito de Santa Rosa, Villa de San Carlos y Yaritagua, por tanto, mientras estuvieran allí, se entendía que "por no poder dichos religiosos percibir el estipendio", los pagos señalados a los curas de aquellos pueblos, se destinaban para adornos de las respectivas iglesias. AGN-C, Real Hacienda, Libro de la Concordia, T. 30, fols. 23vto.-24. 
de las vísperas, misas y procesiones que los indígenas hicieran a su devoción; el donativo por las misas de velorios cuando los desposados lo pidieran, no siendo los domingos, en que los curas estaban obligados a celebrarla para sus feligreses; y la donación por las misas que celebraran a los indígenas muertos, lo cual era obligación del encomendero mandarlas decir y sin que el cura fuera forzado a cantar sin pagársela, pues hasta la sepultura el oficio religioso corría a su cargo. Respecto a este último punto, se remitían a las leyes sobre la materia, o lo que se observara en la provincia.

Resuelta la anterior parte de la normativa, las autoridades pasaron a regular y tasar los estipendios en forma particular, por distinguir que las condiciones socio económicas no se comportaban semejantes para toda la jurisdicción gubernativa. Así pues, determinada la cuenta y si bien la mayoría de las doctrinas no alcanzaban a los 50.000 maravedís de estipendio más los 24 pesos para cera y vino, pues resultaban insuficientes los tributos ante la estimación del corto número de indígenas que existían en ellas, con el deseo de concertar la mejor forma en la paga, la remuneración definitiva se ajustó conforme al trabajo que tuvieran los curas y según el número de feligreses, de manera que los religiosos no se recargaran con más trabajo y asistencia, sino por el que justamente cobraran..$^{56}$

El cálculo se estimaba sobre la base de los indígenas registrados por las matrículas y del tributo que en cada partido se recaudaba, rebajando lo razonable por los nativos que eran relevados de tal obligación por sus oficios, los que enfermaban y los que huían, así como reservando alguna cantidad para las partes donde no alcanzara el tributo, a fin de asegurar ciertos gastos imprevistos y las pensiones impuestas en las encomiendas para la cátedra y soldados. Lo que así sobrara del estipendio se repartiría por meses a razón de 50.000 maravedís al año y 24 pesos para vino y cera, tocando en cada mes 4.166 y $2 / 3$ de maravedís, que hacían los 15 pesos, 2 reales, 18 y $2 / 3$ de maravedís, y los 2 pesos restantes para vino y cera, conforme y como hasta entonces se observaba en la Provincia.

Por la anterior remuneración, los doctrineros se obligaban a residir en el partido señalado y dar la doctrina a sus feligreses durante los meses que

56 Algunos problemas surgirían al momento de su cumplimiento, pues cinco años más tarde, todavía no tenían muy claro el origen de los fondos para satisfacer a los curas doctrineros con tan especial cantidad. Por este motivo, declaraba el gobernador que los 24 pesos se prorratearían entre las encomiendas correspondientes al pueblo de cada doctrina y de allí se sacaría el importe de sus tributos según la porción que regularmente le tocaba a cada encomienda como lo tenía dispuesto el monarca y se hacía con el estipendio, pero que no se tocaran los efectos de comunidad. AGN-C, Real Hacienda, Instrucción de Corregidores, T. 32, fol. 39vto. 
correspondiera con el estipendio que percibieran. Mientras los curas que tuvieran dos o más pueblos, asistirían en cada uno el tiempo que le tocara de acuerdo a la porción que le pagaran los indígenas de cada pueblo y concluirían los meses de instrucción en la ocasión de la Cuaresma y Semana Santa cuando era preciso que residieran en su doctrina.

De conformidad con lo anterior, el obispo y gobernador procedieron, desde junio de 1691 y hasta fines del siguiente año,${ }^{57}$ a tasar los estipendios de los curas doctrineros. Las tareas se iniciaron con los pueblos que hasta entonces habían ordenado y remitido sus matrículas ${ }^{58}$ y, al final, las pocas doctrinas que faltaban se arreglaron a proporción por las autoridades. Por la tasación, también se ajustó la cuenta general sobre los pagos pendientes desde agosto de 1687, cuando los naturales fueron demorados. Un resumen con los totales para esos primeros momentos, es como sigue:

\section{GoBERnACIÓN DE VENEZUELA}

Pueblos e indígenas tributarios ${ }^{59}$ (1691-1692)

\begin{tabular}{lccccr} 
Jurisdicción & $\begin{array}{c}\text { Número } \\
\text { Pueblos }\end{array}$ & $\begin{array}{c}\text { Indígenas } \\
\text { Tributar }\end{array}$ & $\begin{array}{c}\text { Indígenas } \\
\text { /Pueblo }\end{array}$ & $\begin{array}{c}\text { Estipendio } \\
\text { (en Mrs.) }\end{array}$ & $\begin{array}{c}\% \\
\text { Estip. }\end{array}$ \\
\hline Caracas & 26 & 997 & 38 & 535.395 & 27,43 \\
Coro & 13 & 175 & 13 & 134.251 & 6,88 \\
Trujillo & 12 & 915 & 76 & 485.196 & 24,86 \\
Barquisimeto & 8 & 698 & 87 & 208.020 & 10,66 \\
El Tocuyo & 7 & 703 & 100 & 320.324 & 16,41 \\
Valencia & 4 & 446 & 112 & 113.046 & 5,79 \\
Carora & 4 & 352 & 88 & 155.452 & 7,97 \\
\cline { 2 - 5 } Totales= & 74 & 4.286 & 58 & 1.951 .684 & \\
\multicolumn{5}{c}{ Total en pesos= } & 7.175 \\
\end{tabular}

57 Según la documentación, el tiempo durante el cual estuvo en vigencia esa modalidad de tributar los indígenas y la forma como se recaudaban y administraban los estipendios de curas doctrineros se extendió hasta 1786, cuando la contaduría real experimentó una nueva reforma.

58 Hacia finales de 1691, aun cuando faltaban algunas doctrinas pertenecientes a la jurisdicción de ciudades como El Tocuyo, Trujillo, Portillo de Carora y San Sebastián de los Reyes, donde se continuaba con el levantamiento de las matrículas, las autoridades sólo esperaban que llegara la información para reanudar el referido señalamiento; y todavía para mediados del siguiente año no se tenía información sobre algunas doctrinas de las tres primeras ciudades. AGN-C, Real Hacienda, Libro de la Concordia, T. 30, fols. 23 y 29.

59 Ibídem, fols. 130 y ss. 


\section{Efectos del cambio entre los indígenas}

De tan significativa importancia incidieron los cambios que la Corona introdujo en la tradicional organización sociocultural indígena, al tiempo que se producían las reformas en la encomienda, que trastocaron de forma general sus pueblos hasta transformar no sólo su vieja estructura urbana, sino también su concepción política con la pretensión de avanzar hacia el modelo de civilización europeo, occidental y cristiano.

En cuanto al funcionamiento interno de los pueblos, la reorganización se inició con el ejercicio de un nuevo gobierno económico en apariencia compartido. En las doctrinas actuaban, por una parte, los corregidores que entendían sobre lo civil, criminal y, en particular, lo fiscal pues en ellos recaía tanto la cobranza del tributo indígena como la organización y el cuidado de las cajas de comunidad; y por la otra, los caciques quienes supuestamente presidían y administraban las cajas comunales junto con otros miembros electos, pero que sobre cuyas cabezas descansaba el orden y la guarda del nuevo sistema. No obstante, las autoridades que promovían el mentado gobierno económico se dirigieron a liberar de forma inmediata y sin restricción el monopolio de esa mano de obra, cuya oferta finalmente se abrió no sólo a las actividades agrícolas de otras regiones, sino que además de contratarse en condiciones más liberales se incorporó en distintas actividades productivas excedentarias para el mercado nacional.

\section{Reorganización de los pueblos indígenas}

\section{El gobierno de los corregidores}

Durante la gestión del marqués del Casal y ante los progresivos cambios que se introducían en la tributación indígena, paralelamente, el viejo oficio de Corregidor de Indios también experimentó una renovada importancia. ${ }^{60}$ Fue una etapa en que los recién titulados asumieron una serie de

60 Sobre el Corregidor de Indios existe algo menos de una veintena de trabajos para Hispanoamérica. Entre los más recientes tenemos, por ejemplo, Comadran Ruíz, Jorge: "Un corregidor por poder en el Cuyo en el siglo XVII", Revista de Historia del Derecho. N. o 4, Buenos Aires, 1976; Alanís Bayso, José Luis: Corregidores de Toluca: apuntes para su estudio, 1510-1810. México, Biblioteca Enciclopédica del Estado de México, 1976; Moreno Cebrián, Alfredo: "Intendencias, Corregidores y repartos en Perú”, Hispanoamérica hacia 1776. Madrid, S/e., 1980, págs. 227-240; Lucas Nogales, María José: "Las Ordenanzas para Corregidores de Cumaná en 1700”, Temas Americanistas. N. ${ }^{\circ}$ 6, Sevilla, 1986; Anda Aguirre, Alfonso: Corregidores y servidores públicos de Loja. Quito, Banco Central del Ecuador, 1987; Gómez de Acosta, Esteban: Querétaro en 1743: informe presentado al rey por el corregidor Esteban Gómez de Acosta. Santiago de Querétaro, Gobierno del Estado - Archivo Histórico, 1997. 
nuevos compromisos administrativos y si bien su jurisdicción estaba localizada en el perímetro de los pueblos indígenas, su intervención ahora se dirigía hacia lo fiscal, civil y criminal.

Por enero de 1691, el gobernador y capitán general, tras informar ${ }^{61}$ sobre la importancia del instrumento real del 17 de diciembre de 1689, también advertía del papel que en adelante desplegarían los corregidores por las tareas inherentes a su cargo.$^{62}$ Luego de exponer las órdenes reales, tocantes a la libertad del servicio personal de los indígenas y, sobre todo, a la moderación de la tasa tributaria mandó a los corregidores que resultaran nombrados para su recaudación, que abandonaran el cobro de aquel primer monto y restituyeran la demasía recolectada entre los naturales, hasta igualarlos a la segunda tasación.

En la cédula antes citada y fecha referida, entre otras cosas, el monarca confirió al gobernador la facultad para confirmar los corregidores nombrados por su antecesor; pero, tras no acoger el encargo real, procedió a suspender las anteriores designaciones. Ante la necesidad de elegir las personas de toda entereza y a su satisfacción para atender tanto el buen gobierno y cobranza del tributo, como la enseñanza, conservación y defensa de los indígenas, el gobernador Casal estableció que los corregidores fueran españoles, personas de calidad y capacidad, temerosos de Dios, con buena conciencia para su educación, enseñanza de costumbres políticas y mantenerlos en justicia, con conocimiento de la naturaleza indígena, su modo de vivir y experiencia de judicatura para su defensa.

A partir del mismo enero de 1691, el marqués del Casal, luego de resaltar las condiciones y experiencias sobre cada uno de los postulantes, comenzó a nombrar y despachar los nuevos títulos para la administración de los corregimientos. No obstante, acceder al ejercicio de tal oficio, al igual que antes, significaba cumplir con todo un largo protocolo administrativo. ${ }^{63}$ El gobernador si bien mandaba que los candidatos debían consignar ante los jueces de Hacienda las correspondientes fianzas exigidas, pro-

61 AGN-C, Real Hacienda, Libro Copiador, T. 462, fol. 81. Auto del 8 de enero de 1691, ordenado por el marqués del Casal, gobernador y capitán general de Venezuela.

62 Aun cuando Arcila dice que el marqués del Casal inició el nombramiento de los corregidores un año antes, lo más importante será la nueva responsabilidad que tendrán los nominados. Arcila: Economía Colonial, T. I, pág. 100.

63 Muy extenso y casi en iguales términos se repetía el texto de los nombramientos para corregidor, como ocurrió en 1691, por ejemplo, con los títulos de Juan Mexia de Collado (enero); Luis Gerómino Osorio (febrero); capitán Juan de Landaeta (agosto); y, Joseph López de Landaeta (septiembre). AGN-C, Real Hacienda. Libro Copiador, T. 462, fols. 81 y ss. 
badas y abonadas, los montos debían satisfacer las expectativas tanto del cargo como de las autoridades fiscales ${ }^{64} \mathrm{Al}$ momento de presentar los testimonios legítimos y las garantías financieras, en caso de que dieran por suficiente las provisiones, los aspirantes suplicaban lo que fuera de justicia. Vistos los expedientes en la oficina de Contaduría y por auto, el contador certificaba al pie de cada título no sólo la conformidad de las fianzas sino que además se dejaba constancia de que el candidato no era "deudor de su Majestad en ninguna cantidad" y de inmediato lo firmaban los demás jueces oficiales.

El solicitante con los papeles en regla, se presentaba ante el Cabildo, Justicia y Regimiento de la ciudad y a satisfacción tanto de sus miembros como de los jueces de Hacienda allí presentes, consignaba para seguridad de todos, nuevas y convenientes fianzas por donde se comprometía a dar cuenta con pago al final de cada año por los siguientes cargos: 1) de los tributos que en el primer año y los subsiguientes cobrara en los pueblos indígenas según los padrones; 2) sobre los rezagos que restaran en los años antecedentes de conformidad con la minuta y liquidación; 3) por los reales sencillos cobrados anualmente a cada indígena útil para la caja de comunidad; y 4) al término de su ocupación, quedar sujeto a residencia por el oficio y pagar en lo que fuera juzgado y sentenciado en ella. Así hecho y por testimonio, el gobernador ordenaba que les recibieran el juramento pertinente para que se encargaran de los corregimientos, que los aceptaran en su ejercicio y les entregaran la insignia de Real Justicia que debían usar en sus empleos.

El título, para ejercerlo por tres años contados a partir de su nombramiento, lo usarían sólo en los casos y cosas a él referidos. Ya en ejercicio del cargo, si bien los corregidores tenían el control del gobierno local, también debían responder a una serie de obligaciones. A nivel interno y respecto al tratamiento de los indígenas, era de su competencia: 1) cuidar la buena enseñanza de los indígenas, su conservación y aumento; 2) ampararlos del maltrato, forzamiento y violencia al momento de sus compras, ventas y recibir su jornal; 3) defenderlos para que les pagaran enteramente en plata o especie de géneros y frutos por lo que los concertaron y a los plazos señalados, apremiando a los deudores que abonaran sus obligaciones; 4) con lo que procediera de sus jornales y dada su incapacidad, asistirlos

64 Ejercían los cargos de jueces oficiales de la Real Hacienda en Venezuela, los señores Gabriel de Rada, contador; Diego Aguado de Páramo, tesorero; y Juan de Lisardi, factor y veedor. 
para que no existiera dolo contra ellos ni los engañaran en cantidades, precios, medidas y pesos; 5) enseñarlos con palabras amigables a comerciar y que solicitaran lo que les interesara sin ser contra conciencia para su manutención; 6) de igual forma, inducirlos a realizar sus labranzas y sementeras, mostrándoles los tiempos del año así como el temple de las tierras para rozar, sembrar y recoger los frutos, con lo cual no sólo sustentarían sus familias, sino que además olvidarían la ociosidad, embriaguez y el vagar a que estaba inclinados por su naturaleza; y 7) procurar que no les quitaran nada con temeridad y mal trato, defendiéndolos como hombres humildes por su pobreza y paga, procediendo en justicia contra quienes intentaran estos y otros agravios. ${ }^{65}$

En cuanto a lo externo y para profundizar aquellas diligencias, el gobernador mandó a los corregidores, entre otros encargos, la especial protección del indígena frente a los tratantes ilegales y les señalaba: 1) acentuar el cuidado y vigilancia sobre los comerciantes que practicaban el trato ilícito; 2) solicitar la ayuda no sólo de los alcaldes de la ciudad y demás comisionados nombrados para tal efecto, sino también de quienes perseguían a tales negociantes; 3 ) atender a la colaboración y buena correspondencia que existiera entre unos y otros, sin competencias que impidieran el real servicio; 4) dar cuenta al gobernador de lo que obraran, para que el rey fuera bien servido y la patria beneficiada. Por tal comisión, si bien no percibirían salario alguno, se resarcirían con la tercia parte que le tocara de los "descaminos" capturados.

Finalmente sobre la dignidad del cargo, el gobernador establecía, en primer lugar, dirigiéndose por igual tanto a vecinos como estantes y habitantes ${ }^{66}$ que entraran en los pueblos indígenas, la obligación de acatar y respetar al corregidor de aquellos lugares, guardándole todas las gracias, honras, franquezas, libertades, prerrogativas e inmunidades propias del cargo, como ministro de Justicia. En segundo lugar, mandaba a los indígenas y a todas las personas de cualquier calidad y condición, que tuvieran algún litigio u otro pleito con los naturales en lo civil o criminal, que cumplieran con

65 Por los numerosos y extensos documentos de cuidada redacción que entregara el gobernador, se dejó constancia de una amplia normativa que se pudiera entender, como las primeras instrucciones por las que, en adelante, se tendrían que guiar y/o proceder los corregidores.

66 Estas categorías son distintas y de uso corriente en las Indias. En Venezuela, de hecho, las leyes para el buen gobierno provincial clasificaban en tales términos a un sector de la población que siendo de origen hispano, con buena posición social y económica, no tenían el rango de vecinos aunque ya residieran por algún tiempo en distintas regiones de su jurisdicción o simplemente estuvieran de paso; por sus particulares actividades, distinguieron de tal forma a los comerciantes. 
los mandatos del corregidor y acudieran a sus llamados en los plazos fijados, pues, de lo contrario, con igualdad de justicia ejecutaría en los inobedientes las penas impuestas, para que los indígenas fueran amparados y satisfechos sus agravios como vasallos.

\section{La cobranza del tributo}

El marqués del Casal, ya por enero de 1691, conminaba a los corregidores con el objeto de proceder a la cobranza de los tributos indígenas; y si bien aludía sobre algunos inconvenientes, también destacaba las grandes necesidades para iniciar las actividades desde ese mismo año y lo imperioso de continuar en los dos subsiguientes, para cada corregimiento por igual. Lapso durante el cual, no sólo darían razón de los rezagos que resultaran por la gestión, ya fuera en torno al tributo principal de los años antecedentes cumplidos o sobre las restituciones que el rey mandaba, sino también consignarían los registros para observar en particular los negocios y conocer en profundidad la administración con el fin de actuar sobre algunos asuntos. En las entregas de cuentas no se aceptaría, bajo ningún pretexto, gastos por concepto de servicios, fletes de bestias, compras o ventas, ni otra razón de interés, tampoco pedir o cobrar a los indígenas más que los tasados 54 reales a los que estaban en la jurisdicción de las 10 leguas de la capital y 38 reales a los ubicados fuera de ella, y que anualmente pagaría cada uno por los tercios del año. Las penas por lo que hicieran en contrario, se les impondrían en la Residencia. ${ }^{67}$

Disposiciones que continuaron ejecutando los siguientes gobernadores. Así lo evidencia la expedición del mandato real y autos particulares que dirigieron a los alcaldes ordinarios de Valencia, El Tocuyo, Trujillo, Carora y Coro para que entregaran a cada uno de los corregidores la normativa acerca de proporcionar las cuentas sobre la recaudación del tributo que anualmente pagarían los indígenas.

Al cumplir con la cédula dictada en diciembre de 1691, tocó al gobernador Berroterán ${ }^{68}$ por enero de 1694, notificar a los corregidores de su distrito que ejercieron el cargo en los tres últimos años, que dentro de los siguientes 20 días a la notificación y con toda puntualidad dieran los

67 AGN-C, Real Hacienda, Libro Copiador, T. 462, fols. 83-83vto. Auto del 8 de enero de 1691, dictado por el marqués del Casal.

68 AGN-C, Real Hacienda, Instrucción de Corregidores, T. 32, fols. 3-3vto. Auto del 19 de enero de 1694, dictado por el gobernador y capitán general de Venezuela. 
correspondientes descargos ante los jueces oficiales de Hacienda en la capital. Y en cuanto a las ciudades del interior, que dichas autoridades ordenaran lo más eficaz a sus tenientes para que los corregidores entregaran las suyas. ${ }^{69}$ Para exigir el entrego de cuentas y acatar la ley, nuevamente se despacharon autos a las justicias ordinarias de aquellas ciudades con el fin de obligar a su cumplimiento, so pena, contra los alcaldes y corregidores que no las dieran dentro del término señalado, de 100 pesos que se aplicarían para la fábrica de la cárcel de Caracas. Cantidad que no sólo ejecutarían en cada uno, sino que a costa de aquellos la traerían y, concluidos los trámites administrativos, las justicias remitirían sus testimonios..$^{70}$ En tanto a los corregidores en ejercicio, les recordaba que desde enero de 1694 llevaran la formalidad conveniente sobre la cobranza del tributo indígena y que:

su distribución y formación de las dichas cajas de comunidad y buena administración en todo lo que se le comete y que ha de dar cuenta con pago a fin de cada año, guardará, observará y cumplirá lo dispuesto en la instrucción que para el efecto se le da, a que se reglará cumpliendo sus capítulos y cada uno de ellos con las prevenciones y formaciones de libros para mejor inteligencia o claridad de toda buena cuenta, dándomela primero para que se provea lo conveniente y más favorable a dichos indios. ${ }^{71}$

\section{Las Cajas de Comunidad}

Durante esta década y por distintas cédulas se mandó a los gobernadores que para la mejor conservación, aumento y reparo de las necesidades de los indígenas debían formarse las cajas de comunidad $^{72} \mathrm{y}$, para ello, cada

69 Esta injerencia del gobernador en los asuntos privativos de la Real Hacienda se hizo cada vez más directa a partir del siguiente año, cuando Berroterán acusó a los ministros de no cumplir con la responsabilidad de ajustar y liquidar las cuentas de lo que percibían los corregidores por concepto de tributación indígena. Los jueces oficiales respondieron, a manera de excusa, que si bien existía algún retardo, éste se debía, en parte, a la escasez de personal para recibir tal volumen de cuentas locales, pero también porque los corregidores faltaban al cumplimiento de su obligación. No obstante, el gobernador sólo prevenía respecto a los daños que recibirían los encomenderos y curas doctrineros. Ibídem, fols. 114vto-117vto.

70 Todavía para el año de 1695, el gobernador insistía en la necesidad de solicitar información de los corregidores para conocer por esta vía la situación general de la Provincia; con excepción de El Tocuyo y Trujillo, que ya la habían remitido. Ibídem, fols. 45 y 48.

71 AGN-C, Real Hacienda, Libro Copiador, T. 462, fol. 136vto. Auto del 4 de febrero de 1694, dictado por Francisco de Berroterán.

72 Además de las amplias referencias de Arcila y Suárez sobre las Cajas de Comunidad, los trabajos aun cuando muy escasos, por ahora, contamos con los estudios de Escobedo Mansilla, Ronald: "Bienes y Cajas de Comunidad en el virreinato peruano", Revista de Sociología. N. 32, Madrid, 1979, págs. 465-492; y, Martín Rubio, María del Carmen: "La Caja de Censos de Indios del Cuzco", Revista de Indias, N. ${ }^{\circ} 155-158$, Madrid, 1979, págs. 187-208. 
indígena depositaría anualmente los estipulados dos reales sencillos. ${ }^{73}$ Correspondió al marqués del Casal no sólo acoger la orden, sino que pareciéndole aquello conforme por necesario acordó, por enero de 1691, que se procediera a formar las cajas con toda anticipación y al menor costo posible, teniendo en cuenta que cualquier gasto corría con cargo a la cuenta de los ya señalados reales que entregaran los indígenas. En la participación de tales cajas, sólo concurrirían los indígenas útiles que estuvieran en la condición de encomendados o bien libres bajo la administración de la Corona. ${ }^{74}$

Debió ser muy lenta dicha empresa, pues tres años más tarde Francisco Berroterán por un nuevo auto de 1694, se acogía a lo que le ordenaba el rey sobre "la conservación, aumento y reparo de las necesidades de los indios". Acatando el mandato y tras considerarlo de nuevo conveniente, mandó que se formaran las cajas de comunidad y, donde no estuvieran hechas, que procedieran con tal diligencia y en los términos del caso, guardando toda prudencia y el menor costo posible, para que anualmente cada indígena abonara los dos reales señalados. La construcción de la cajas, si bien se continuó financiando por cuenta de los propios indígenas, correspondió a los corregidores en cada pueblo de su corregimiento organizar su fábrica y control:

de un arca segura con tres llaves distintas, la una que tenga el mismo corregidor, otra el alcalde ordinario indio en primer voto que lo sea de la dicha población y la otra, el cacique de la encomienda que tuviere más indios del dicho pueblo en la cual entren las cantidades que fructuare la cobranza y paga de los dichos dos reales, con la cuenta y razón conveniente..$^{75}$

Desde ese último año fue tarea de los corregidores, por disposición particular, que se dedicaran a la organización de las cajas de comunidad en todos los pueblos indígenas de su corregimiento. Junto a ello no sólo estaba la fabricación de un arca segura, constituida por el cajón con sus tres cerraduras y llaves en distintas personas, sino también lo conformaba la

73 Suárez afirma, en este caso, que: "Los fondos de las cajas de comunidad se emplean para socorrer a los enfermos, ancianos y huérfanos, para construir puentes, caminos, acequias y hospitales, para pagar los tributos de los indígenas y solventar sus rezagos, para otorgar préstamos agropecuarios, para costear misiones desarraigadoras de idolatrías y, en general, en benefico común de los naturales". Suárez, Los Fiscales, pág. 364.

74 AGN-C, Real Hacienda, Libro Copiador, T. 462, fols. 83-83vto. Auto del 8 de enero de 1691, dictado por el marqués del Casal.

75 Ibídem, fols. 136. Auto del 4 de febrero de 1694, dictado por Francisco de Berroterán. 
buena administración, pues en ellas entrarían las cantidades en que fluctuara la cobranza de los dos reales que pagaban los indígenas y para cuya gestión contaban con la buena y proporcionada cuenta y razón. ${ }^{76}$ Por este concepto los indígenas aportaban interanualmente a las cajas por vía de ahorro, la tentadora cantidad de 8.572 reales (1.071,5 ps.), cuando para la misma fecha, el sueldo anual de un oficial de hacienda llegaba a los 735 pesos y un esclavo que era la mercancía más costosa, apenas alcanzaba a los 225 pesos de promedio.

\section{Liberación de la mano de obra}

\section{Eliminación de trabas legales para contratar}

Con el cambio que le impusieron a los naturales cuando establecieron la demora del tributo, los beneficiarios inmediatos de la reforma fueron precisamente los mismos que recibieron las antiguas mercedes indígenas. Tras la desaparición del servicio personal y tan sólo a pocos años de iniciarse la nueva forma de organizar y explotar la fuerza de trabajo aborigen, los vecinos encomenderos pasaron a legalizar por este medio y en forma sutil la vieja costumbre tantas veces denegada por la ley. Fue así como en algunas parcialidades indígenas, sus encomendados finalmente entraron en una progresiva movilización, por cuya práctica se llevaron de unas a otras regiones, con diferentes climas y temperaturas, para trabajar en las apartadas haciendas agrícolas o ganaderas.

Un recurso que si bien estaba prohibido desde antiguo, se siguió manteniendo pues, por ejemplo, ya desde enero de 1695, lo denunciaba Joseph Ramírez de Arellano, corregidor del pueblo de Quara. ${ }^{77}$ En la información que remitió al gobernador, no sólo refería que allí existía una encomienda "tan grande" que pasaba en número de las 200 familias, dada por el gobierno anterior a Martín de Tovar, vecino de Barquisimeto, sino que además precisaba, que si bien 100 familias eran de nación Chipas con pueblo en el sitio desde antaño, los restantes eran Caquetíos y, por ser de distinta nación,

76 Ante las denuncias sobre la distracción de los bienes de comunidad, la Corona además de incitar al mayor control de aquellos haberes, ordenó que las tres llaves unas veces estuvieran en manos del cacique, del alcalde indígena y del corregidor; otras en las del sacerdote, un cacique y un indígena; y otras en las del gobernador indígena, un alcalde y un mayordomo. Suárez, Los Fiscales, pág. 367.

77 AGN-C, Real Hacienda, Instrucción de Corregidores, T. 32, fols. 78-78vto. Joseph de Arellano, corregidor de Quara al gobernador y capitán general de Venezuela. 
los últimos estaban separados desde el tiempo del servicio personal en el sitio de Chivacoa, hasta donde los condujeron para que asistieran a las labores de labranza que en la región tenía el encomendero. Concluía diciendo el corregidor, "de tal suerte, que no ha sido fácil reducirlos a este pueblo y permanecen en el dicho sitio".

La averiguación se llevó por consulta al obispo y tan pronto como se informara sobre el problema, al siguiente mes le respondió al gobernador. ${ }^{78}$ El obispo Diego Baños y Sotomayor tras confirmar que en el sitio de Chivacoa, términos de Barquisimeto, se encontraban más de 100 familias indígenas de nación Caquetíos y que pertenecían a la encomienda del sargento mayor Martín de Tovar, en su opinión la culpa sólo recaía en el anterior encomendero, a cuyo sitio forzaron a los indígenas en tiempos cuando se mantenía en servicio personal. En aquella época, la acción se dirigió a emplearlos en el beneficio de las haciendas que tenía en tan apartados lugares $\mathrm{y}$, sobre todo, para que cómodamente y con puntualidad asistieran al trabajo.

Continuaba explicando el obispo que por tal razón y en poco tiempo ocurrió lo previsto, pues los indígenas se adaptaron en aquel paraje, de modo que con mucho peligro no sería fácil obligarlos a poblar en otro lugar. Por lo cual prevenía que de ser asignados a la feligresía del valle de Quara, donde residía el resto de las familias indígenas Chipas y estaba constituida la original encomienda, nunca se llevarían amigablemente por ser naciones distintas y enfrentados constantemente. Al final, el prelado advertía que de ello se derivarían algunos inconvenientes, no siendo el de menor consideración que a dos leguas de distancia desde Chivacoa a Quara, ordinariamente los indígenas se quedaban sin oír misa por no concurrir ni mezclase unos con otros.

Vistos los informes y con la anuencia del obispo, el gobernador, tras confirmar el traslado, al final reconocía y justificaba que por estar ya habituados en aquel sitio, así como lejos de su pueblo y doctrinero, para que no careciesen más del auxilio espiritual, los agregaba a la doctrina más cercana. Concluidas las diligencias del caso, de inmediato surgieron diversos inconvenientes conflictivos no sólo entre los indígenas, sino también entre los encomenderos y doctrineros lo que, en ciertos momentos, hasta exigió la intervención de la autoridad competente.

78 Ibídem, fols. 80-80vto. El obispo Diego Baños y Sotomayor al gobernador y capitán general de Venezuela. 


\section{Dispersión de la mano de obra}

Las reformas también afectaron de inmediato la tradicional organización del trabajo indígena, lo cual generó un amplio desplazamiento de naturales y, con ello, la dispersión de mano de obra. Desde entonces, fue muy corriente que en la información remitida al gobernador sobre los pueblos indígenas, se denunciara sobre los numerosos naturales que abandonaban sus encomiendas para buscar aventajadas condiciones de vida, tanto por un mejor tratamiento que en otros lugares ya recibían, como por el necesario trabajo para complementar el pobre sustento de sus familias. ${ }^{79}$

De una abundante información al respecto, tenemos por ejemplo, un auto del gobernador Berroterán, fechado en agosto de 1696, donde advertía que por información del capitán Manuel de Lunda, corregidor de San Carlos de Austria y San Francisco, sitio de Messi, jurisdicción de Caracas, sabía que muchos indígenas se ausentaban de sus pueblos y carecían no sólo del apoyo espiritual, doctrina y enseñanza política, sino que además, no se encontraban para la cobranza de los tributos que debían pagar al rey y sus encomenderos. Por tal razón mandaba:

a los caciques y justicias del dicho pueblo, bayan a cualesquier partes de la provincia donde supieran que hay dichos indios e indias, mayores y menores, y los traigan, y acojan al dicho pueblo, usando para ello de todos los medios de suavidad y blandura, y en caso necesario, se valgan de las justicias y jueces de las partes donde se hallaren; a todos los cuales y a los demás súbditos ordeno y mando, les den el auxilio que necesario fuere para que tenga cumplimiento y efecto lo aquí contenido. ${ }^{80}$

Al siguiente mes y por otro auto, en tono un tanto de amonestación, señalaba que "personas celosas del servicio real y bien común de la república" le avisaban que muchos indios de los corregimientos, tras desamparar sus encomiendas se ausentaban hacia otras jurisdicciones y en cuyas

79 Por estas décadas finales del siglo, son muchos los indígenas encomendados que se escapaban y se refugiaban en los trabajos del Real de Minas de San Francisco de Cocorote, a propósito de la explotación del cobre. Numerosos pleitos de encomenderos contra los gobernadores (cuando el estanco) y luego contra sus dueños (ya privatizada) se ventilaban tanto en las residencias como en las visitas a la mina, donde se constataba la ocupación de estos indígenas en las distintas labores de la producción en las minas. Consultar al respecto, Acosta Saignes, Miguel: "Vida de los negros e indios en las minas de Cocorote durante el siglo XVII", Estudios Antropológicos en homenaje al doctor Manuel Gamio. México, Universidad Nacional Autónoma de México, 1956, págs. 555-573; Arcila, El régimen, pág. 256.

80 AGN-C, Real Hacienda, Instrucción de Corregidores, T. 32, fol. 120. Auto del 14 de agosto de 1696, mandado por Francisco de Berroterán. 
haciendas mientras unos se concertaban, otros vagaban en su entorno o por los valles de la costa. Aun cuando los corregidores de sus partidos y los indígenas gobernadores hacían las diligencias para retornarlos a sus encomiendas, no lo podían cumplir, por cuanto en muchas regiones además de no admitir las requisitorias, reaccionaban contra aquellas autoridades y sus indígenas acompañantes a quienes ultrajaban y despedían con oprobio y vejaciones. Ante tales hechos y para que en adelante no se experimentara semejante daño, que recibía la república y los encomenderos, el gobernador ordenó que por ninguna razón se permitiera a los indígenas que vivieran en las regiones donde no era naturales, y por tanto demandaba:

\begin{abstract}
a los tenientes de justicias, capitanes a guerra, corregidores y demás jueces, y súbditos míos que fueren requeridos con este despacho o testimonio de él, por las personas que fueren a buscar y recoger a sus pueblos con requisitorias de sus corregidores a los indios que anduvieren ausentes de ellos, les den todo el favor y ayuda que para dicho efecto necesitan ${ }^{81}$
\end{abstract}

Ante cualquier desacato, el gobernador prevenía que no sólo actuaría contra ellos como desobedientes a los mandatos de la Justicia, sino que además, se les harían rigurosos cargos sobre los perjuicios, malas consecuencias y daños que por tales infracciones se siguieran, apoyados en la mera relación de su oposición a los indígenas gobernadores, caciques y demás personas que fueran con las requisitorias. Por tal resistencia se les condenaría a un año de servicio personal, a su costa y en la fuerza del puerto de La Guaira, con lo demás que se reservaba como arbitrio por convenir así al servicio de Dios, al alivio de la república y puntual recaudación del real interés, como del que debían percibir los encomenderos de sus tributos. Para su cumplimiento, el despacho se remitió con testimonio a los cabildos de la gobernación, en cuyas jurisdicciones se refugiaban los indígenas tributarios.

\title{
Conclusión
}

Tras la llegada del obispo Baños y Sotomayor con encargos tan precisos y junto a la buena gestión del gobernador marqués del Casal, fue la oportunidad para que en la provincia de Venezuela se ejecutaran una serie

81 Ibídem, fols. 122-122vto. Auto del 2 de septiembre de 1696, ordenado por Berroterán. 
de órdenes reales que hasta entonces y por diversas medios la Corona intentaba armonizar, como era la triple racionalidad entre el trabajo de los naturales, la percepción del tributo indígena y los cambios que ocurrían en la estructura productiva.

En tal sentido, la pervivencia de una producción menor, como sementeras y otros cultivos menores realizados por los indígenas para el autoconsumo y un mercado muy local, comenzó a crear significativos problemas entre los encomenderos, pues aquella tradicional actividad productiva había entrado en una profunda crisis que se expresaba en la progresiva disminución de su rentabilidad. Lo relevante durante este coyuntural proceso fueron los cambios que sufrían tanto los sectores sociales como el económico, pues, considerando las tendencias predominantes de una producción excedentaria, si bien el encomendero día a día se transformaba en esclavista, la producción en general y el cacao en particular rápidamente evolucionaba hacia una economía de plantación para el comercio regional y nacional.

En estas condiciones y lejos del católico celo real por la protección del indígena, los beneficios de las reformas recayeron de nuevo en la propia Corona y los vecinos. Por una parte, mientras el erario real entraba a percibir nuevos y mayores ingresos, liberaba a los encomenderos de las antiguas responsabilidades de protección y evangelización del aborigen. Por la otra, mientras los agricultores o ganaderos y algunos artesanos en las ciudades contrataban aquella mano de obra en condiciones más liberales, daban las pautas para el surgimiento y formación de un nuevo sector social: el peón asalariado. Por ello, la incorporación del indígena a las nuevas actividades económicas, permitió principalmente a los sectores terratenientes no sólo contratarlo en trabajos hasta entonces prohibidos, sino que generó un cambio en la forma de obtener una mayor explotación de la fuerza de trabajo indígena.

Finalmente, es necesario advertir sobre la equivocada y cada vez más generalizada idea de que a partir de 1687 desapareció el régimen de encomienda en Venezuela; pues la práctica no fue eliminada hasta 1821. Lo que realmente ocurrió en las últimas décadas del siglo XVII fue un cambio en la organización y administración del sistema de explotación indígena, evidente en la desaparición del tributo en "servicio personal", para establecer la tributación en "dinero" o su equivalente en especie. 